Article

\title{
Incumbents' Strategies in Media Coverage: A Case of the Czech Coal Policy
}

\author{
Ondřej Černý and Petr Ocelík * \\ Department of International Relations and European Studies, Masaryk University, 60200 Brno, Czech Republic; \\ E-Mails: cernyondra@mail.muni.cz (O.Č.), ocelik@mail.muni.cz (P.O.) \\ * Corresponding author
}

Submitted: 31 October 2019 | Accepted: 29 February 2020 | Published: 2 June 2020

\begin{abstract}
Transitioning to a decarbonized economy is a crucial part of climate change mitigation, with the phasing-out of coal, as the most significant source of carbon dioxide emissions, being the centerpiece of this effort. In the European context, the increasing pressures exerted especially on the basis of the European Union's energy and climate policy, coupled with the inherent uncertainty of the transition process, encourage various struggles among the involved policy actors over the setting of specific transition pathways. One site of such contestation is media discourse, which may facilitate or limit policy change through agenda-setting, framing, and other processes. Importantly, discursive struggles also include industry incumbents, who have a vested interest in preserving the existing sociotechnical regime. This article focuses on the position of incumbents in terms of their relationship with governing political parties and the discursive strategies they employ. It explores the policy debate on coal mining expansion which took place in 2015 in the Czech Republic, a post-communist country with a coal-dependent economy, a skeptical position on energy transition, and a powerful energy industry. The research employs discourse network analysis to examine a corpus compiled from daily newspapers and applies block modeling techniques to analyze patterns of relationships within and between actor groups. The results show that incumbents successfully prevented policy change in the direction of rapid coal phase-out by exploiting discourse alignment with governing parties and efficiently employing discursive strategies based primarily on securitization of socioeconomic issues.
\end{abstract}

\section{Keywords}

coal; Czech Republic; energy; discourse network analysis; media discourse; newspapers; public policy

Issue

This article is part of the issue "Policy Debates and Discourse Network Analysis" edited by Philip Leifeld (University of Essex, UK).

(C) 2020 by the authors; licensee Cogitatio (Lisbon, Portugal). This article is licensed under a Creative Commons Attribution 4.0 International License (CC BY).

\section{Introduction}

Transition to a decarbonized economy is a crucial part of climate change mitigation efforts. Coal, which has been used as a reliable and cheap energy source since the beginning of the industrial revolution, now accounts for $27 \%$ of global primary energy supplies, and its share in total $\mathrm{CO}_{2}$ emissions is $44 \%$ (International Energy Agency, 2018). Thus, energy transition requires a rapid coal phase-out. The European Union has devised a plan to stop coal production over a horizon of 25 to 50 years (European Commission, 2017), which generates pressure especially on incumbent coal producers who resist and negotiate such change (Geels, 2014). The nature and pace of energy transition is thus contested by diverse policy actors and their coalitions who compete to influence the related policy process (Markard, Suter, \& Ingold, 2016; Ocelík et al., 2019).

Mass media are an integral part of this struggle as they provide visible sites for policy debates on transition-related challenges, thus defining for audiences what are (non)legitimate policy responses and who authoritatively speaks about them (Johnstone, Stirling, \& Sovacool, 2017; Stoddart \& Tindall, 2015). Likewise, Leifeld (2013) argues that policy actors' media struggles constitute a "discursive layer of subsystem politics" and actors can be classified into "coalitions of competing policy beliefs" through which they promote their inter- 
ests (see Hajer, 1995; Sabatier, 1988). Shanahan, Jones, and McBeth (2011) contend that coalitions generate and strategically use particular narratives tailored to promote preferred policy outcomes. Consequently, political discourses affect agenda-setting processes, public opinion dynamics, and policy actors' interactions, and have the potential to facilitate particular policy outcomes (Leifeld, 2017). More generally, a discursive shift where one dominant coalition is replaced by another is considered a precondition of major policy change (Hajer, 1993; Leifeld, 2013; Shanahan et al., 2011). Thus, the study of political discourses is critical for better understanding energy transitions requiring major policy changes.

In this research, we present a single-case study that examines (1) whether energy industry incumbents, i.e., actors that benefit most from the prevailing system (Smink, 2015), aligned with governing political parties, and (2) what discursive strategies incumbents employed to prevent policy outcomes from facilitating coal phaseout (Johnstone et al., 2017). The case is one of a mature, adversarial policy subsystem (Weible, 2008) with a well-established coalition structure consisting of two competing coalitions (see Ocelík et al., 2019). Based on the above, the overarching research question is the following:

RQ: How did the position of incumbents in the media discourse on coal phase-out evolve over the course of the year 2015 ?

To that end, we use discourse network analysis (Leifeld \& Haunss, 2012), which allows us to capture actors' discursive interactions over time. We analyzed a media coverage corpus consisting of the relevant articles from daily newspapers in the Czech Republic. To examine discourse alignment between incumbents and governing parties, we used deductive block modelling (Saunders, 2009).

This research strives to make two contributions. Firstly, by linking policy process (Leifeld, 2016; Sabatier, 1988) and energy transition literatures (Geels, 2002; Johnstone et al., 2017), it explores the role of incumbents in preventing transition-oriented policy change through discursive interactions. Secondly, the research brings novel empirical evidence on a major European coal consumer which is neither committed to a specific phase-out pathway (such as Germany), nor actively opposing that policy option (such as Poland; see Lehotský, Černoch, Osička, \& Ocelík, 2019; Osička et al., 2020).

\section{Theory: A Discursive Layer of Energy Transition}

Energy transition constitutes a major technological transformation in the way fundamental societal functions are fulfilled, such as housing, transportation or feeding (Geels, 2002). Such change is, nevertheless, limited by path-dependencies of an established socio-technical regime- a set of embedded rules and practices that enables and constrains actors in relation to the existing en- ergy system (Geels, 2014). Thus, the formulation of specific transition pathways assuming different cost and benefit structures is being contested by diverse policy actors and their coalitions (Markard et al., 2016). In this context, we use the Advocacy Coalitions Framework (Sabatier, 1988), which posits that policy processes involving various interdependent actors take place mostly within specific policy subsystems defined by particular issue areas. It further assumes that since actors cannot achieve most of their goals alone, they tend to form 'coalitions of the like-minded' centered around highly salient policy beliefs concerning how the policy subsystem should be organized (Henry, Lubell, \& McCoy, 2011). Energyrelated subsystems are expected to involve coalitions of right-wing and industry organizations, with the principle actors being incumbents, vis-à-vis coalitions of leftwing and environmental organizations, with the principle actors being environmental NGOs (ENGOs; see Ingold, Fischer, \& Cairney, 2017; Ocelík et al., 2019). Industry incumbents possess superior organizational resources and privileged access to decision-making authorities (Geels, 2014). ENGOs, however, try to offset their lower organizational resources and limited access to decision-making through media visibility and other outsider strategies (Dalton, Recchia, \& Rohrschneider, 2003).

Weible (2008) proposed that coalition interactions are conditioned by the subsystem characteristics, specifically by the degree of policy belief compatibility and prevailing coordination patterns. Adversarial subsystems are then defined by competing coalitions with low-level between-coalition belief compatibility (Weible, Pattison, \& Sabatier, 2010). Competing coalitions exercise power against each other through different means, including by shaping public opinion and thereby affecting the decision-making of political authorities (Leifeld, 2016; Weible et al., 2010). Media discourse is a key arena where diverse actors engage in policy debates and struggle to shape public understanding of contested issues (Broadbent et al., 2016; Kukkonen, Ylä-Anttila, \& Broadbent, 2017; Leifeld, 2013). Thus, coalitions strive to promote their narratives designed to convince other actors about a particular policy position (Shanahan et al., 2011). To capture coalition dynamics at the discourse level, we employ the concept of 'discourse coalitions,' defined as "groups of actors who share a social construct" (Hajer, 1993, p. 43).

To resist regime change, incumbents use instrumental, institutional, material, and discursive strategies (Geels, 2014). Instrumental strategies employ various actor-specific resources such as positions of authority, money, or access to media in direct interactions with other actors to pursue their interests. Lobbying government to promote regime protection policies is an example of this strategy. Institutional strategies are based on resonance of incumbents' actions and interests with deeper ideological and governance structures that thereby assist in resistance to regime change. Paternalistic decision-making dominated by technical 
and economic expertise, traditionally 'owned' by incumbents, is a component of such institutional context (see Osička \& Černoch, 2017). Material strategies then utilize technical capabilities and financial resources to maintain and improve the technical dimension of the current socio-technical regime. For instance, investments in carbon-intensive technologies reinforce technological lock-in and path-dependencies, which in turn structurally condition policy choices. Geels (2014) gives the example of carbon capture and storage technology, which has also significantly contributed to a 'clean coal' discourse. Finally, discursive strategies focus on shaping public discourses in order to establish a regime-protective dominant discourse. This allows incumbents to control the complementary processes of agenda-setting (McCombs \& Shaw, 1972), i.e., what is discussed, and framing (Snow \& Benford, 1988), i.e., how is it discussed.

Johnstone et al. (2017) offer a useful typology of 'incumbents' strategies' that allows to further distinguish the specific ways they shape public and policy discourses to secure their interests. First, 'securitization' frames the incumbents' interests, such as expansion of coal mining, as matters of national or regional security. Appeals to supply security that contrast coal as a reliable domestic source to import dependency-inducing natural gas or volatile renewables would be consistent with such strategy. Second, 'reinvention' reframes the current regime and its core components in a way that appears new or innovative. So-called clean coal technologies are a prime example here. Third, 'masking' suppresses, socializes or externalizes the full costs of the incumbent regime. For example, incumbents typically choose to be silent on issues of the environmental degradation and health impacts of coal mining. Fourth, 'capture' promotes incumbents into positions of political or regulatory power. In this respect, the 'revolving doors' phenomenon blurs distinctions between public and private interests, making it unclear who speaks for whom (Johnstone et al., 2017).

\section{Data and Methods}

The analyzed corpus consists of all articles concerned with the topic in the major national newspapers which satisfy the 'quality press' criterion (Leifeld, 2013) as well as regional newspapers in the impacted regions: Karlovy Vary, Liberec, Plzeň, and Ústí nad Labem. Specifically, this included all four major daily newspapers Mladá fronta Dnes, Právo, Lidové noviny, and Hospodářské noviny, peripheral Haló noviny (closely linked to the Communist Party); and 11 regional newspapers (Deník) issued under Vltava Labe Press publishing house. The editorial ideology of the major national newspapers ranges from the traditional social-democratic perspective of Právo, through Mladá fronta Dnes' centrist position, to the liberal right in the case of Lidové noviny and Hospodářské noviny (for more, see Volek \& Urbániková, 2017). It is worth noting that then chairman of junior governing party ANO 2011 and Finance Minister Andrej Babiš ac- quired the MAFRA publishing house that issues Lidové noviny and Mladá fronta Dnes.

Data was collected through the Anopress IT Czech media monitoring database (Anopress, n.d.) based on the following keyword search query (English/Czech keyword): coal/uhlí $<A N D>$ ((mining/těžba $<A N D>$ limits/limity) $<O R>$ energy industry/energetika $\angle O R>$ limits/limity). The query construction avoids too narrow focus by adding keyword phrase energy industry, which allows us to capture incumbents' discursive strategies that do not explicitly mention the mining limits-such as statements on the role of coal in the energy mix. The time frame was set between 1 January 2015 and 21 October 2015 to cover the policy debate on the mining limits between the government's announcement of the reevaluation process and its final decision.

All articles were read and their contents manually coded if actor statements (1) referred to relevant policy positions or responses (e.g., 'mining limits need to be preserved') or (2) represented normative evaluations of relevant issues (e.g., 'coal mining has severe environmental impacts'; Koopmans, 2002). Both direct and indirect (reported) statements have been coded. The coding was done in Discourse Network Analyzer (Leifeld, 2019). Each coding unit (statement) was defined by four variables: concept, organization, person (if available/relevant), and dis/agreement with the concept. Although coding allowing to test inter-coder reliability was not applied, we used the following procedure to increase data quality. Firstly, an initial coding scheme consisting of a smaller number of concepts derived from literature was formulated. Secondly, a multipass coding strategy where a single coder navigates back and forth between the statements in order to increase coding consistency was employed (Leifeld, 2013). There was a first reading of the corpus followed by regular meetings with the second researcher during which ambiguities in the coding were addressed and resolved. This included revisions of the coding scheme to reflect new information. Lastly, there was a joint discussion on classification of the concepts under the incumbents' discursive strategies (see Table 1).

The coding of 705 relevant articles yielded 890 coding units with 34 concepts and 43 organizational actors (for more information, see Appendix 3 of the Supplementary File). The actors were classified under four categories: (1) incumbents, (2) governing parties, (3) ENGOs, and (4) none of the above (residual group). This classification reflects the focus on the relationship between the incumbents and governing parties while controlling for the main regime challengers, ENGOs. Governing parties were Social Democrats, ANO 2011, and Christian Democrats. Incumbents were defined as organizations that mostly benefit from the current regime (see Smink, 2015) and would directly profit from the mining expansion. Preserving the limits, to the contrary, would incur costs to them. The incumbents include state-owned energy company ČEZ Group and its subsidiary North Bohemian Mines, private min- 
Table 1. Incumbents' discursive strategies: Classification scheme.

\begin{tabular}{|c|c|}
\hline Strategies & Concepts \\
\hline Capture & The state should be involved in coal mining (agreement) \\
\hline Masking & $\begin{array}{l}\text { Coal mining has no negative impacts if it does not interfere with settlements (agreement) } \\
\text { Moving the mining further away from settlements sufficiently reduces its negative impacts (agreement) } \\
\text { Coal mining and use of coal have negative health impacts (disagreement) } \\
\text { Coal mining produces high negative externalities (disagreement) } \\
\text { Rescission of limits will cause environmental degradation (disagreement) }\end{array}$ \\
\hline Reinvention & $\begin{array}{l}\text { The combination of underground and surface mining is less harmful (agreement) } \\
\text { Coal is a key source for the heating industry (agreement) }\end{array}$ \\
\hline Securitization & $\begin{array}{l}\text { Preserving the limits will bring regional socioeconomic decline (agreement) } \\
\text { Preserving the limits will cause serious regional unemployment (agreement) } \\
\text { Coal is a strategic commodity (agreement) } \\
\text { Coal is needed to replace power supplies from the nuclear-power plant Dukovany (agreement) } \\
\text { According to the State Energy Policy coal beyond the limits in the ČSA mine is not needed (disagreement) }\end{array}$ \\
\hline
\end{tabular}

ing companies Sev.en and Sokolov Coal, as well as the Bohemian-Moravian Confederation of Trade Unions and the Heating Industry Association. Regime challengers, on the other hand, aim to disrupt and change the status quo. Nevertheless, only ENGOs have been included since countervailing industry actors, such as renewable energy companies, did not engage in the debate. The ENGOs group includes Friends of the Earth, Glopolis, Greenpeace, and Limits Are Us. Finally, though local organizations, mostly municipalities and civil associations, do not necessarily pursue regime change, some are concerned with the immediate impacts of mining expansion, such as destruction of settlements. Hence, the residual group consists of a heterogeneous set of actors such as opposition and regional political parties, research organizations, local civic organizations, and other NGOs.

The incumbents' discursive strategies were identified based on the subsequent theory-driven classification of particular concepts into four categories: capture, masking, reinvention, and securitization (Johnstone et al., 2017). We used a classification scheme consisting of 13 concepts capturing specific features of the four strategies (see Table 1). The remaining 21 concepts have not been explicitly linked to any of the strategies. Thus, occurrence of dis/agreements with particular concepts or the absence of agreement with particular concepts (masking) indicated use of a specific discursive strategy.

We extracted matrices for (1) actor congruence networks consisting of organizations and (2) bipartite (affiliation) networks consisting of organizations and concepts for all three stages. The actor congruence networks have weighted ties that represent organizations' cumulative similarity in their use of concepts. Thus, the more similar the position in the discourse, the higher the edge weight. We further used average activity normalization (Leifeld, 2013), which accounts for the presence of highly involved actors such as relevant ministries. More specifically, the edge weight is normalized by dividing its value by the average number of concepts both actors refer to, either through negative or positive statements, in the affiliation network. The threshold values for dichotomization were set in an explorative way (Leifeld, 2013). Normalized actor congruence networks were used to explore the coalition structure of discourse. We defined discourse coalitions as groups or organizations that (1) exclusively agreed or disagreed with one of the four limit rescission variants and (2) have been identified as part of a cohesive subgroup (for more information, see Appendix 2 of the Supplementary File).

The affiliation networks have weighted ties resulting from subtraction of disagreements from agreements (see Leifeld, Gruber, \& Bossner, 2019). The next step was to dichotomize the underlying incidence matrices. Since we are interested in similarity patterns among organizations, we used the following threshold: if $w>0$, then 1 , otherwise 0 . In other words, all positive ties were transformed to $1 \mathrm{~s}$ and all negative ties were transformed to $0 \mathrm{~s}$. There are two reasons for such approach. First, we argue that more restrictive thresholds are appropriate rather for one-mode projections that tend to overestimate density and clustering than for bipartite networks. Second, a more restrictive threshold would also discard patterns of ties where actors express a low-level agreement (e.g., $w=1$ ) with a large number of concepts resulting in a loss of potentially important information.

The resulting incidence matrices were used to calculate of row-based (organization-based) square similarity matrices using Jaccard's coefficient (Hahsler, 2019). Jaccard's coefficient $(J)$ calculates the similarity of two sets (here organization profiles) as the number of common elements (intersection of the two sets) divided by the sum of the number of elements in both sets (union of the two sets). Thus, J ranges between $\langle 0,1\rangle$ and can be readily interpreted as the percentage of overlap between the two sets, with 0 indicating no overlap and 1 complete overlap.

To examine a discourse alignment between incumbents and governing parties, we used deductive block 
modelling. A block model is a simplified representation of a network that consists of groups of nodes (blocks) that have similar relations to others and similar patterns of relations among nodes and blocks (social roles; see White, Boorman, \& Breiger, 1976). Deductive block modelling then involves the definition of a hypothetical model based on theoretical assumptions (see Saunders, 2009)-here, similarity of governing parties and incumbents in terms of used concepts - which provides a baseline for the observed network. Thus, each block model divided the corresponding similarity matrix into four groups based on organization membership in (1) incumbents, (2) governing parties, (3) ENGOs, and (4) none of the above (residual group). The resulting $4 \times 4 \mathrm{im}$ age matrix represents the average similarity values for the within-group blocks (diagonal) and between-group blocks (non-diagonal). Thus, similarity (discourse alignment) between the two actor groups, such as incumbents and governing parties, is indicated if the corresponding between-group block average similarity value is statistically significantly higher than the overall average (network) similarity.

In order to determine whether the observed block averages statistically significantly differ from the network (overall) average, we used a permutation test. More specifically, statistical significance was assessed based on a comparison of the observed block similarities with the interval estimate of the overall average (network) similarity constructed for the $95 \%$ confidence level from a generated sampling distribution with 5,000 trials. The sampling distribution was generated based on Jaccard's coefficient measurements of the 5,000 random bipartite networks with the same number of nodes in both node sets and with a tie formation probability set to the density calculated for the dichotomized incidence matrix of the observed network.

We used R 3.3.1 (R Core Team, 2014) for data processing and analysis, specifically the packages arules (Hahsler, 2019), rDNA (Leifeld, Gruber, \& Henrichsen, 2019), and sna (Butts, 2008).

\section{Results}

The debate on the mining limits' rescission proceeded in three stages. More specifically, the decision to review the territorial limits (see Figure 1) was part of a coalition agreement establishing the new government in early 2014 (first stage). The majority government was led by the Social Democrats and included two junior coalition partners, technocratic populist ANO 2011 and Christian Democrats. Having analyzed the situation, at the end of 2014 the Ministry of Industry and Trade proposed the following four potential options:

1. To preserve the current territorial limits;

2. To rescind the limits in the Bílina mine;

3. To rescind the limits in the Bílina mine and partially also in the ČSA mine;

4. To rescind the limits in the Bílina mine and also in the ČSA mine.

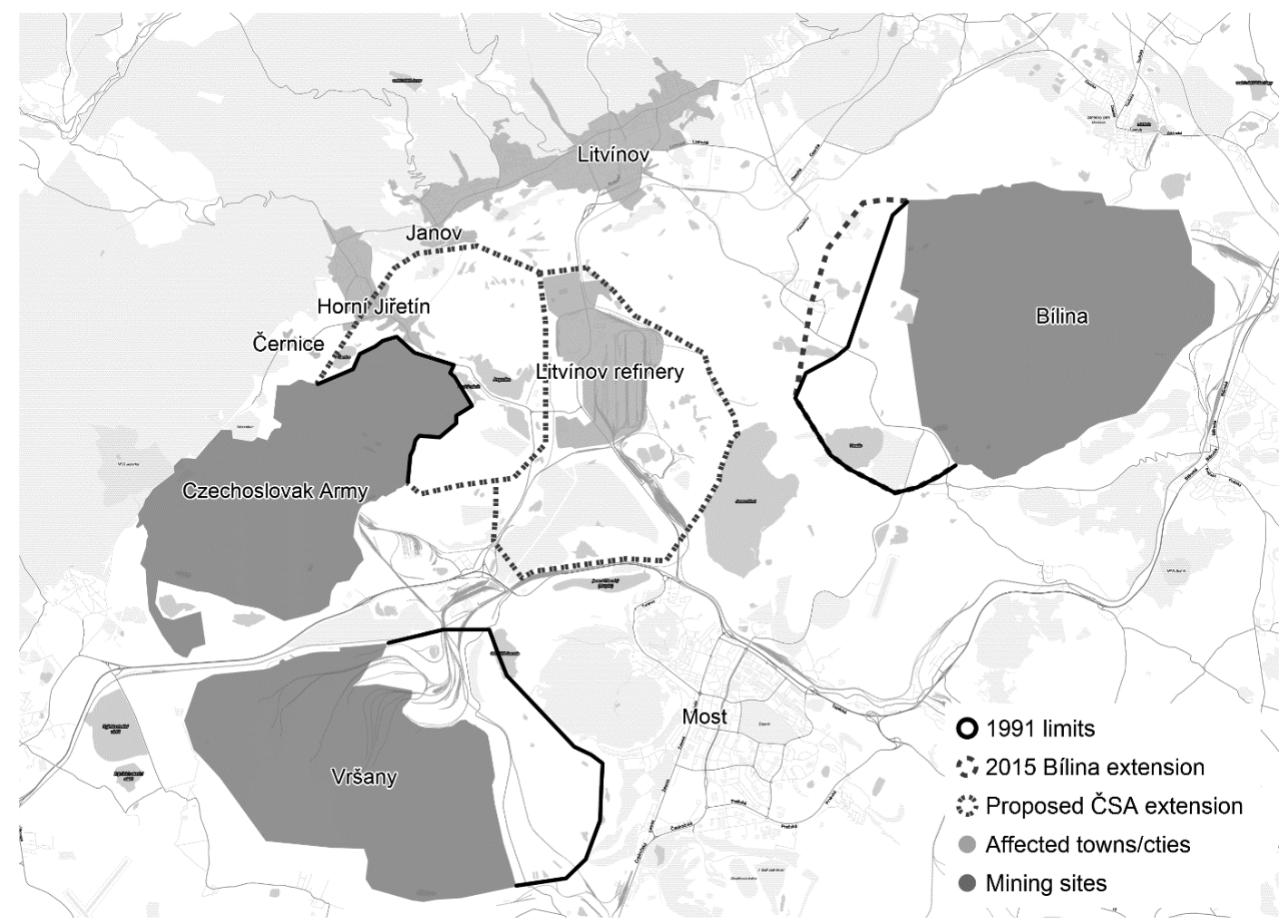

Figure 1. Territorial-ecological limits and mining sites in the North Bohemian (Most) Basin. Source: Adopted from Lehotský et al. (2019). 
Initially, rescission of the limits was supported mainly by industry incumbents and the Minister for Industry and Trade. This, however, stirred a substantial public debate, and at the beginning of 2015 the two junior coalition parties decided to oppose the change. To resolve this stalemate, it was agreed that further analyses would be made to better understand the consequences of each option, to which end the government commissioned impact evaluation studies (second stage).

In May 2015, an important amendment of the State Energy Policy envisaging a shift in the energy mix from coal-based production to a greater role of nuclear energy was adopted (Ministry of Industry and Trade, 2015). Subsequently, the impact evaluation studies published at the turn of August and September (third stage) argued that only the coal reserves in the Bílina mine were needed to cover future coal demand. After these developments, the junior coalition partners changed their position, and on 19 October 2015, the government reached the decision to rescind the territorial limits in the Bílina mine (option 2). For more information, see Appendix 1 of the Supplementary File.

This section presents a description of the normalized actor congruence networks and block modelling results for each stage. The former represents organizations' belief overlap and maps coalition structure of the discourse (Leifeld, 2013), while the latter shows organizations' similarities within and across four pre-defined groups: incumbents, governing parties, ENGOs, and residual group. A summary of incumbents' discursive strategies is presented in Section 4.4 .

\subsection{First Stage (January-April 2015): Incumbent Mobilization}

The government's announcement of the mining limits' reevaluation in early January 2015 sparked a heated debate. The actor congruence network (Figure 2) contains the largest number of actors (39) while exhibiting a marked segmentation into two competing coalitions.

The industry coalition ( $\mathrm{N}=18$ ), led by incumbent actors Sev.en (private mining company) and the BohemianMoravian Confederation of Trade Unions (BMCTU), is organizationally heterogeneous and, importantly, also includes the Social Democrats (SD), which occupied the Ministry of Industry and Trade as well as the Prime Minister's Office. Another notable actor is the President of the Czech Republic Miloš Zeman (Pre), a long-term supporter of industry incumbents. Two regional political parties belong to the coalition as well, the Communist Party (CP) and populist party Dawn of Direct Democracy (DDD). Having traditional ties to the coal mining regions, the Social Democrats are by far the most active, with 106 statements, while the private coal mining company Sev.en ranks second with 55 statements. The industry coalition emphasizes socioeconomic benefits of mining expansion, especially in terms of job security, mining royalty incomes, and regional development.

The environmental coalition $(N=14)$ consists of ENGOs, grassroots organizations, local municipalities, research organizations, the Green Party, and four local organizations of political parties. The local Green Party organization in Horní Jiřetín (GP-J), a municipality at risk

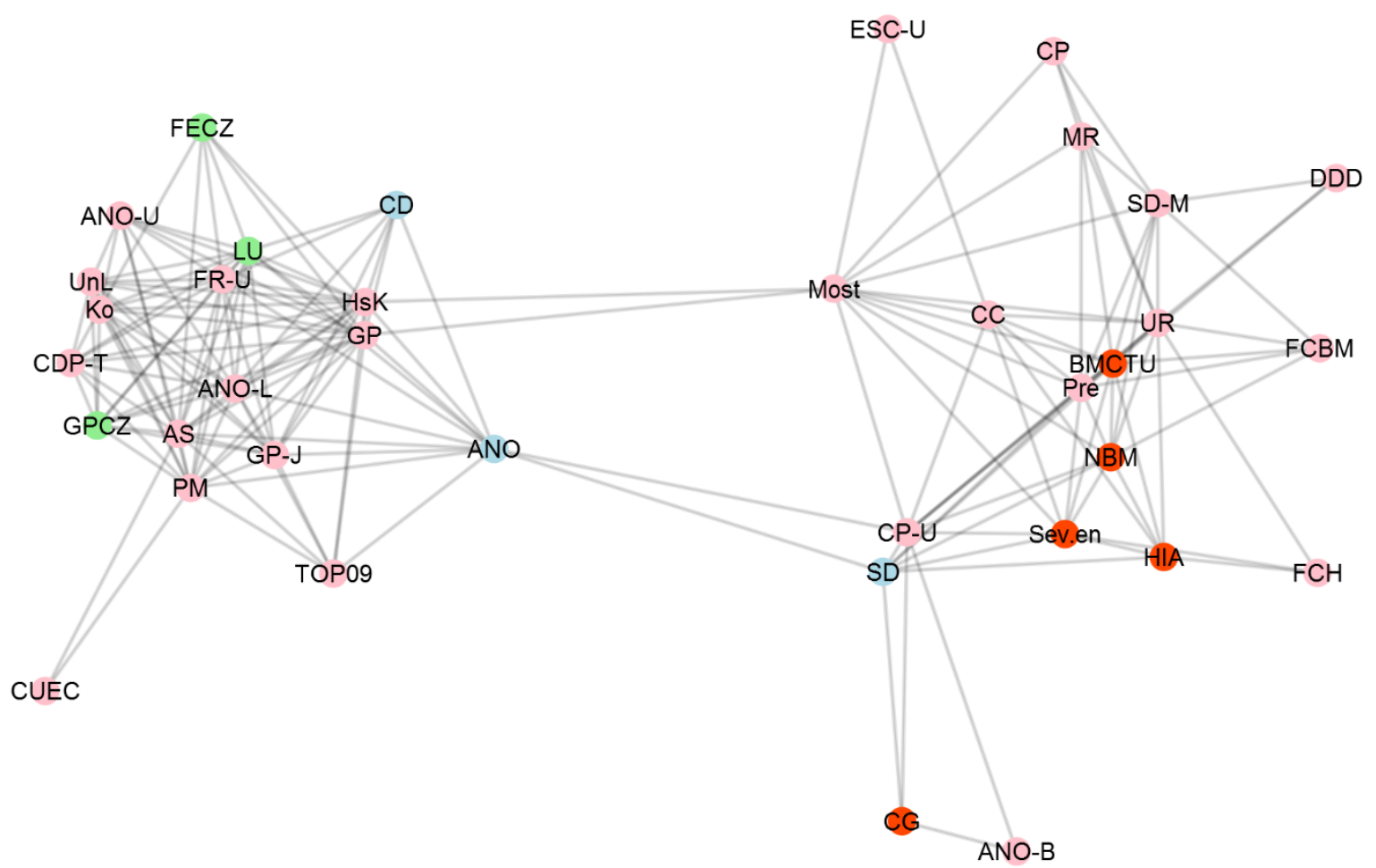

Figure 2. Normalized actor congruence network ( $w>0.727)$. Notes: Incumbents are coded as red, governing parties as blue, ENGOs as green, and residual actors as pink. Isolates are not displayed. 
of destruction in more extensive variants of the limits' rescission, is the most active with 17 statements. The coalition promotes counter-arguments based primarily on negative environmental and health impacts, other concepts are represented only marginally.

The other two governing parties, the Christian Democrats (CD) and ANO 2011 (ANO), for which the mining limits represent a less important issue, are positioned between the two coalitions. Both parties acknowledge arguments concerning socioeconomic benefits as well as negative environmental and health impacts.

The blocked actor Jaccard's similarity matrix (see Table 2) shows a statistically significantly higher similarity between the incumbents and the governing parties (block 1-2) as well as between the governing parties and ENGOs (2-3). To the contrary, the between-group block 1-3 involving the incumbents and the ENGOs exhibits statistically significantly lower similarity approaching a zero-belief overlap. Except the block 3-4, all other between-group blocks are not statistically significantly different from the overall average $(\mathrm{J}=0.092)$. Lastly, all within-group similarity values are statistically significantly higher indicating relative cohesiveness of the four actor groups. These results provide supportive evidence for the presence of two discourse coalitions with a low belief overlap led by the incumbents and ENGOs. They further show that incumbents aligned with the governing parties already in the initial stage of the policy debate.

\subsection{Second Stage (May-August 2015): Incumbent Retreat}

The second stage, marked by the amendment of the State Energy Policy in May 2015 (Ministry of Industry and Trade, 2015), shows a very different picture where only the most active of actors remain present. In comparison to the previous stage, the actor congruence network (Figure 3 ) is less segmented and contains only 17 actors. The governing parties (Social Democrats and ANO 2011) remained centrally located and bridged between the incumbents and a cluster of environmental and local actors.

The industry coalition ( $N=5$ ) includes only one incumbent actor (the Bohemian-Moravian Confederation of Trade Unions, BMCTU); three political parties (Social Democrats [SD], a regional organization of the Communist Party, Ústecký [CP-U], and a local organization of ANO 2011 [ANO-B]); and the municipality of
Mariánské Radčice (MR). Interestingly, the remaining incumbent actors, i.e., the mining companies North Bohemian Mines (NBM) and Sev.en, have not been vocal in terms of public support of the rescission. This could be interpreted in a way that they preferred rather instrumental strategies since the final decision was made at the governmental level. As in the previous stage, the group articulated issues referring mostly to the negative socioeconomic impacts resulting from preservation of the limits, especially those of regional unemployment and supply shortages in the heating sector.

The environmental coalition $(N=5)$ consists of ENGO Limits Are Us (LU), the Green Party (GP), the regional political party North Bohemians (NB), the local Green Party organization in Horní Jiřetín (GP-J), and the municipality of Litvínov (Lit). The Limits Are Us organization was established directly in response to the governmental proposal to rescind the mining limits and soon started a public campaign based mostly on direct action. Thus, its repertoire of contention differs from longer-established ENGOs such as Greenpeace and Friends of the Earth, who rely more on media campaigns and advocacy. The absence of these organizations is rather surprising and indicates their reactive position in the debate. The coalition maintained its focus on local environmental and health impacts of coal mining.

The governing party ANO 2011 remains in a bridging position between the two coalitions, while the Christian Democrats are not present. This might be related to the fact that the Christian Democrats' electoral base in the concerned regions is weak.

The blocked actor Jaccard's similarity matrix (see Table 3) showed a markedly different pattern in comparison to the previous stage. The results indicate that the discourse alignment between the incumbents and governing parties (block 1-2) has not been stable over time and incumbents might have chosen to avoid confrontation in media. It should be noted that, the different variants of the limits' rescission (see Section 3) would have substantially different implications for the individual incumbents. For instance, the partial rescission in variant 2 was beneficial for the state-owned ČEZ Group but would keep the limits in place at the ČSA mine, owned by the private company Sev.en. Thus, the incumbents' positions became fragmented, as the statistically significantly lower similarity value of their within-block (1-1) shows (overall average $\mathrm{J}=0.129$ ). The ENGOs have not been successful to shift the views of ANO 2011 or the

Table 2. Block model: Reduced Jaccard's similarity matrix (January-April 2015).

\begin{tabular}{|c|c|c|c|c|}
\hline & 1. Incumbents & 2. Governing parties & 3. ENGOs & 4. Residual group \\
\hline 1. Incumbents & 0.168 & & & \\
\hline 2. Governing parties & 0.132 & 0.290 & & \\
\hline 3. ENGOs & 0.008 & 0.104 & 0.181 & \\
\hline 4. Residual group & 0.082 & 0.104 & 0.159 & 0.166 \\
\hline
\end{tabular}

Notes: The cells represent Jaccard's similarity values for the corresponding blocks. The cell values statistically significant at $p<0.05$ level are in bold. 


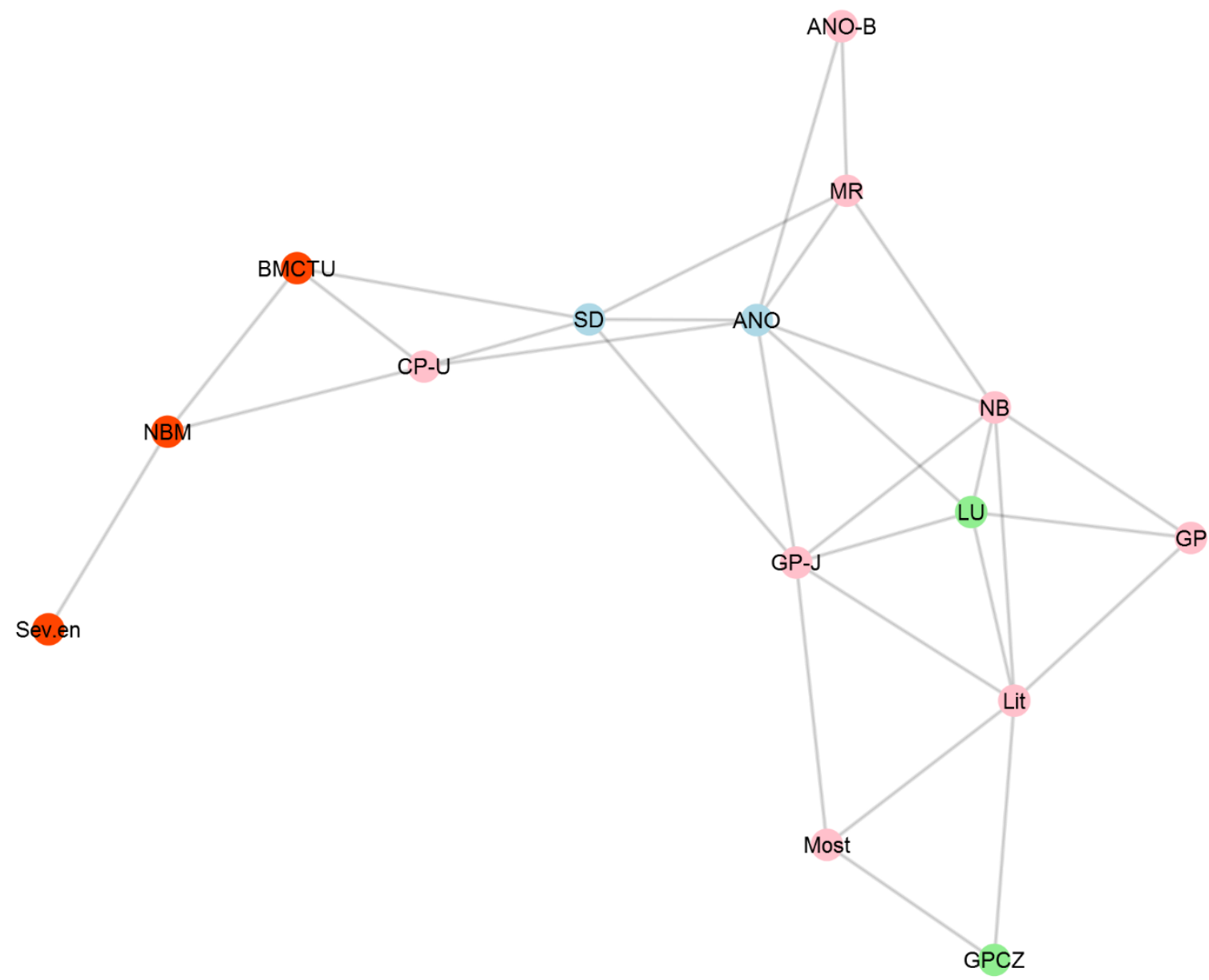

Figure 3. Normalized actor congruence network ( $w>0.439$ ). Notes: Incumbents are coded as red, governing parties as blue, ENGOs as green, and residual actors as pink. Isolates are not displayed.

Christian Democrats in their favor, and thus have moved to a peripheral position.

\subsection{Third Stage (September-October 2015): Incumbent Dominance}

The publication of the impact studies at the turn of August and September 2015 revived the debate as actors began commenting on its conclusions and recommendations until the government's final decision on 19 October 2015. The actor congruence network (Figure 4) contains 25 actors who are, similarly as in the first stage, segmented into two competing coalitions.
The industry coalition ( $\mathrm{N}=12$ ) now consists of two out of the three governing parties (Social Democrats and Christian Democrats) as well as incumbent actors, specifically state-owned energy utility ČEZ Group, Heating Industry Association, and the Bohemian-Moravian Confederation of Trade Unions. The group further includes Czech president Miloš Zeman (Pre), as well as the Communist Party both at the national and regional level (CP-U), a chamber of commerce (CC), a regional authority (ESC-M) and two municipalities (Mariánské Radčice [MR] and Most). The coalition maintains its socioeconomic development narrative while highlighting the argument that mining expansion is necessary for securing

Table 3. Block model: Reduced Jaccard's similarity matrix (May-August 2015).

\begin{tabular}{|c|c|c|c|c|}
\hline & 1. Incumbents & 2. Governing parties & 3. ENGOs & 4. Residual group \\
\hline 1. Incumbents & 0.056 & & & \\
\hline 2. Governing parties & 0.106 & 0.200 & & \\
\hline 3. ENGOs & 0.000 & 0.111 & 0.000 & \\
\hline 4. Residual group & 0.031 & 0.089 & 0.210 & 0.124 \\
\hline
\end{tabular}

Notes: The cells represent Jaccard's similarity values for the corresponding blocks. The cell values statistically significant at $p<0.05$ level are in bold. 


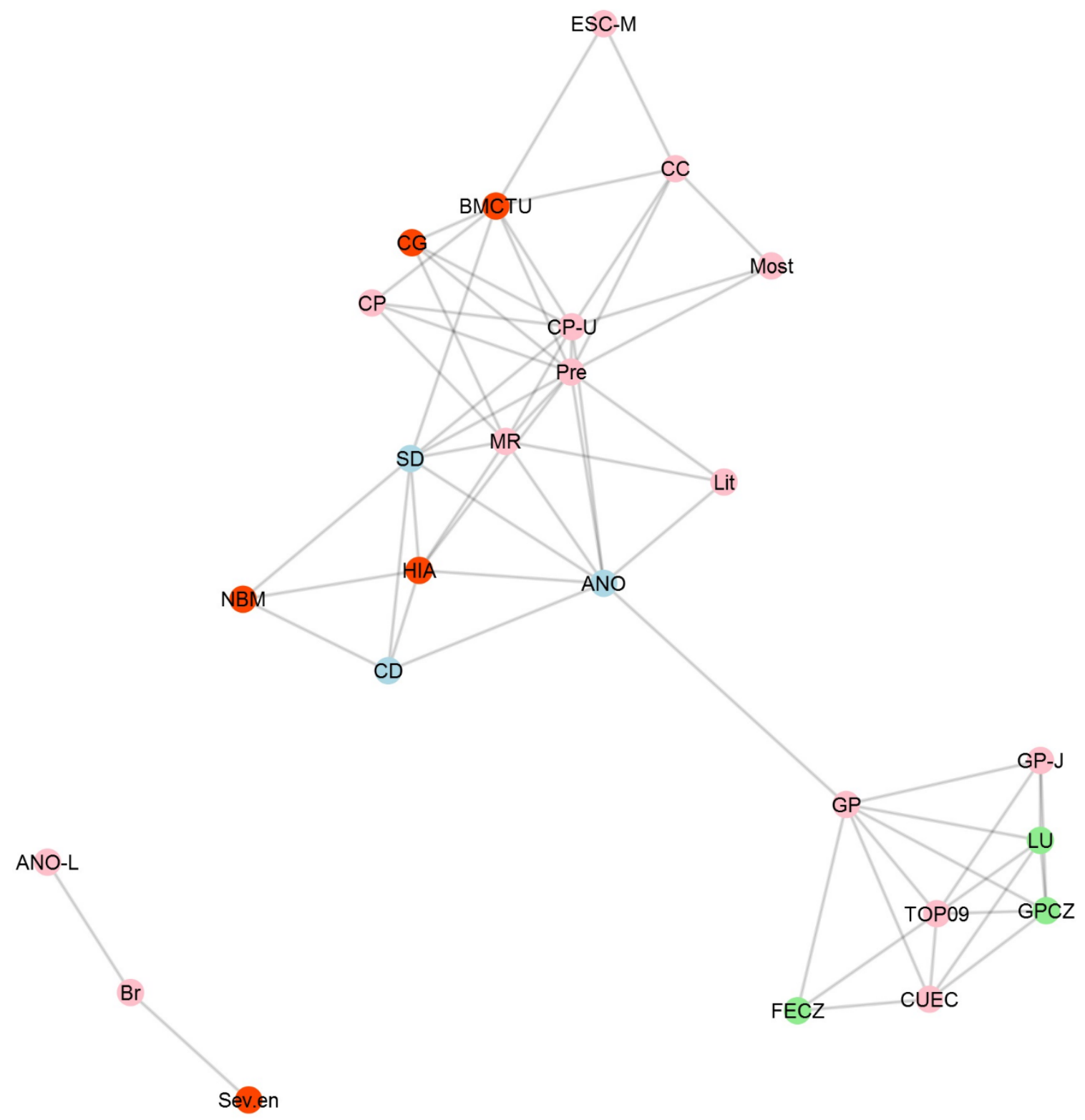

Figure 4. Normalized actor congruence network: Third stage ( $w>0.5)$. Notes: Incumbents are coded as red, governing parties as blue, ENGOs as green, and a residual group as pink. Isolates are not displayed.

heat supplies. Further, it is emphasized that the planned expansion will not lead to removal of settlements which implies preserving the limits at the ČSA mine owned by Sev.en.

The environmental coalition ( $N=6$ ) consists of two ENGOs (Greenpeace [GPCZ] and Limits Are Us [LU]), the Green Party at both the national and local levels (GP-J), the liberal party TOP09, and Charles University Environment Centre (CUEC). The coalition re-affirms the negative environmental and health impacts of mining expansion and newly emphasizes the issue of royalty rate increases to account for the coal miningrelated externalities.

The blocked actor Jaccard's similarity matrix (see Table 4) shows a similar picture as in the first stage. Importantly, the discourse alignment between the in- cumbents and governing parties (governing parties) was renewed (block 1-2). Likewise, the ENGOs and residual group block exhibits a statistically significantly higher similarity from the overall average $(J=0.108)$. In contrast to the previous stages, the similarity between ENGOs and governing parties is statistically significantly lower. The same applies to all remaining between-group blocks, which suggests increased segmentation of the discourse. The within-group similarities are above the overall average for the governing parties and ENGOs. This shows that the ENGOs' reconsolidation coupled with the newly introduced socioeconomic issue of royalty rates was insufficient to influence the debate and was rather a response to the expected outcome of a partial rescission. The incumbent group, consistently supported by the Social Democrats, therefore succeeded in aligning 
Table 4. Block model: Reduced Jaccard's similarity matrix (September-October 2015).

\begin{tabular}{lcccc}
\hline & 1. Incumbents & 2. Governing parties & 3. ENGOs & 4. Residual group \\
\hline 1. Incumbents & 0.126 & & & \\
2. Governing parties & $\mathbf{0 . 1 5 5}$ & $\mathbf{0 . 3 0 4}$ & $\mathbf{0 . 2 5 0}$ & \\
3. ENGOs & $\mathbf{0 . 0 0 0}$ & $\mathbf{0 . 0 7 2}$ & $\mathbf{0 . 1 3 0}$ & 0.096 \\
4. Residual group & $\mathbf{0 . 0 6 9}$ & $\mathbf{0 . 0 6 9}$ & \\
\hline
\end{tabular}

Notes: The cells represent Jaccard's similarity values for the corresponding blocks. The cell values statistically significant at $p<0.05$ level are in bold.

the remaining two governing parties to their side, although ANO 2011 did not explicitly agree with the limits' rescission, and consistently promoted a socioeconomically based narrative.

\subsection{Incumbents' Discursive Strategies}

When linking the distribution of concepts to the four discursive strategies (Johnstone et al., 2017), securitization is the most present (see Figure 5). This strategy is based mostly on socioeconomic arguments (27\% of the incumbents' total). More specifically, incumbents emphasize job security (14\%) and general socioeconomic decline (12\%) which is not surprising since the concerned region is the poorest in the Czech Republic. However, framing coal as a strategic commodity that prevents import dependency and as a reliable source of electricity that, in contrast to renewables, stabilizes the supply grid is only marginally present (1\%). Securitization appeals related to the foreseen phase-out of nuclear power plant Dukovany and the updated State Energy Policy which envisages a declining role for coal in energy mix are absent.

Masking was marginally present through the argument that the removal of settlements is the most serious obstacle to potential mining expansion (2\%). Not surprisingly, this concept is used by the company North Bohemian Mines, which operates the Bílina mine, where the limits' rescission does not imply settlement removal, contrary to the ČSA mine owned by Sev.en. Nevertheless, masking can also be seen as the absence of concepts referring to environmental, health, and other negative impacts of coal mining and use. Of the 73 total statements referring to these concepts, incumbents made only 3 of them ( $2 \%$ of the incumbents' total). There are also very

\begin{tabular}{|l|}
\hline$\square$ First stage \\
$\square$ Second stage \\
$\square$ Third stage \\
$\square$ Total \\
\hline
\end{tabular}

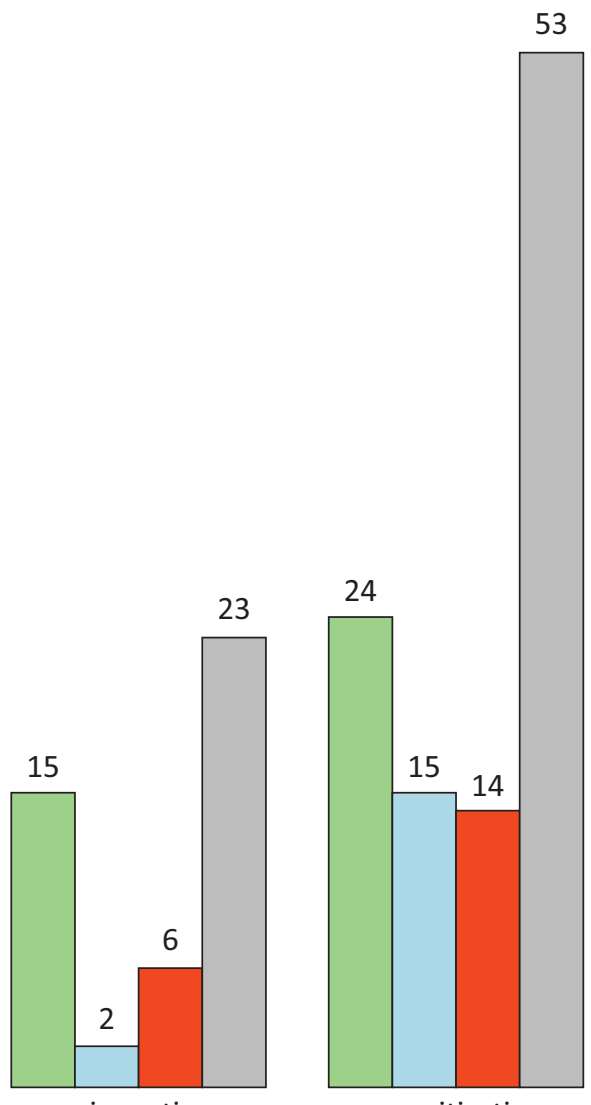

Figure 5. Frequencies of incumbents' discursive strategies. 
few direct disagreements with these concepts (3 out of 197 incumbent statements), which indicates that incumbents decided not to engage in direct confrontation with the environmental coalition.

Reinvention is present mainly through portrayals of coal as a vital source of heating supplies (7\%). Although such use of coal is not innovative, by shifting the emphasis from electricity generation to heating supplies, incumbents have 're-invented' the critical importance of coal for the future energy mix. Importantly, this argument was later declared by the government as a key reason for rescinding the limits at the Bílina mine. As another example, the method of combined surface and underground mining being described as less harmful in terms of local impacts is marginally present (1\%).

Capture can be explicitly linked only with the promotion of the state's direct involvement in coal mining as articulated by private company Sev.en (3\%). Sev.en proposes a joint venture project with the state as a shareholder and argues that such arrangement would ensure efficient as well as fair cost-benefit distribution of the mining expansion. It is important to add that the company North Bohemian Mines is owned by another incumbent actor, ČEZ Group, whose majority shareholder is the Czech government. Thus, Sev.en attempted to follow a model which would decrease its control over the reserves but ensure continuation of mining at the ČSA mine.

\section{Discussion and Conclusions}

This article analyzed the evolution of the Czech media discourse on coal in 2015-the year the government decided to partially rescind the coal mining limits, thereby substantially postponing the coal phase-out. The two research objectives were followed. First, we examined discourse alignment between incumbent actors and governing parties (Geels, 2014; Smink, 2015) within the context of an adversarial subsystem (Ocelík et al., 2019; Weible, 2008). As expected in energy-related subsystems (Ingold et al., 2017), we identified two antagonistic coalitions, a dominant industry coalition led by incumbents and a minor environmental coalition led by ENGOs. The discourse alignment was reinforced even before the decision on the mining limits, which was favorable to most of the incumbents, was made. Second, we explored the discursive strategies used by incumbents (Johnstone et al., 2017), mostly relying on securitization appeals emphasizing job security and economic decline arguments.

The discourse alignment between incumbents and governing parties varied across the three stages. In the first stage, the socioeconomic narrative formulated by incumbents resonated well with the Social Democrats' policies and mobilized support of the allied, mostly regional, actors. This is consistent with Smink's (2015) argument that incumbents tend to refer to general issues which are only indirectly linked to their interests. In the second stage, following the amendment of the State Energy Policy, the alignment between incumbents and govern- ing parties vanished. We offer two explanations here. First, it could be due to incumbents' move toward instrumental strategies (Geels, 2014) based mostly on lobbying and advocacy activities (see Ocelík et al., 2019). The efforts of the most active incumbent, Sev.en, to establish a joint venture with state participation, as well as its proposal to buy out properties that would be removed if more extensive variants of the limits' rescission were adopted, provide supportive evidence (cf. Vlček et al., 2019). Second, since the government declared it would decide based on the results of impact studies, the discourse as such shrunk and policy actors awaited the studies' publication in order to consider their results before formulating their subsequent strategies. In the third stage, two out of the three governing parties joined the industry coalition, thus securing its dominant position before the government's decision. This was facilitated by the inferior position of the environmental coalition, which was unable to expand to include new members that would challenge the status quo (Shanahan et al., 2011).

As for discursive strategies, our findings show that incumbents skillfully employed a mix of strategies, consisting mostly of securitization complemented by reinvention and masking (Johnstone et al., 2017). Incumbents highlighted the risks of increased unemployment and regional economic decline (securitization) while emphasizing the vital role of coal for heating supplies (reinvention) and concealing the negative externalities of coal mining (masking). Rather surprisingly, securitization based on the expected increase of import dependency due to coal phase-out was only marginally present (cf. Lehotský et al., 2019). This is a striking difference from Polish discourse where coal is seen as a material guarantee of energy sovereignty and security of energy supplies (Osička et al., 2020). Although capture, a blurring of public and private interests, was also only marginally represented, we argue that the long-term partnership between the Social Democrats, which controlled the Ministry of Industry and Trade, and incumbents, especially the ČEZ Group, supports the interpretation that such arrangement was already in place (see Osička \& Černoch, 2017). Moreover, Lehotský et al. (2019) documented that over the long term, the Czech media discourse has emphasized the economic problems of mining companies rather than environmental or other negative impacts as a public issue.

As a result, incumbents successfully established "a winner's tale" (Shanahan et al., 2011), i.e., a coherent and persuasive narrative which, as Smink (2015) argued, provides much wanted order in complex situations. Such narrative diffuses benefits, in this case framed as regional development, and concentrates costs, minor impacts on local communities, to portray the status quo, i.e., continuation of mining, as positive (Baumgartner \& Jones, 1993; Shanahan et al., 2011). As Shanahan et al. (2011) argue, coalitions with coherent narratives more likely influence policy outcomes. Likewise, Leifeld and 
Haunss (2012) posit that successful coalitions are stable over time in terms of both their core actors and frames integrated into a consistent story line.

We argue there are three major policy implications. First, regime challengers need to create coherent narrative(s) that do not rely only on particular issues but provide an alternative vision for the subsystem and, more generally, future regime organization that is appealing also to wider audiences. This requires coordination at the coalition level (see Schmidt, 2008), as well as efforts to involve key actors, such as policy-makers and regional authorities, in constructing the regime-challenging narratives. Narratives promoted by incumbents should be explicitly and persistently confronted, in order to increase overall polarization of the debate (Černoch, Lehotský, Ocelík, Osička, \& Vencourová, 2019), potentially contributing to the disintegration or weakening of the dominant incumbent-led coalition (see Leifeld, 2013). Second, a regime-challenging coalition needs to be inclusive. It should consist not only of usual suspects such as environmental movement actors led by professional ENGOs and countervailing industries, but also research organizations, providing scientific expertise, as well as regional and local actors from transition-affected areas, providing legitimacy. Thus, a participatory mode of activism (Petrova \& Tarrow, 2007) should be utilized due to its high mobilization and advocacy capacities, which are critical for coalition expansion. Third, better understanding of how incumbents engage in discursive struggles is useful not only to challengers but also to policy-makers, which are expected to occupy a brokerage position and facilitate between-coalition policy learning (Leifeld, 2013). This further implies that policy-makers should systematically obtain and consider inputs and policy proposals also from minor coalitions (see Smink, 2015). The establishment of policy venues (Fischer \& Leifeld, 2015) to facilitate this process is an advisable step.

This research of course has certain limitations to be addressed. First, it is a single case study focused primarily on novel empirical evidence, which implies limited generalizability of the results. Moreover, the study omits incumbents' non-discursive strategies. Second, it uses descriptive and exploratory methods for coalition detection and discursive strategies analysis, which limits the evaluation of uncertainty.

Considering the above, there appear to be two promising directions for future research. First, application of inferential methods to coalition detection would be a logical next step. Second, expanding the research scope to non-discursive incumbent strategies that could also be integrated into a comparative framework seems especially promising.

To conclude, this study examined the role of incumbent actors in the Czech media discourse on coal within the context of an adversarial subsystem. The results showed that incumbents successfully prevented policy change to rapid coal phase-out pursued by the environmental coalition through a discourse alignment with governing parties and efficient use of discursive strategies. The industry coalition's dominant position was further strengthened by two other factors. First, the combination of the incumbents' strategy to avoid direct confrontation with opponents and the inferior position of the environmental coalition, which did not challenge incumbents' socioeconomic narrative, contributed to a lower level of discourse polarization. Second, the adversarial nature of the subsystem (Ocelík et al., 2019) limited the potential for between-coalition learning, which could have eroded the industry coalition's dominant position by shifting some of its members to the environmental coalition as early adopters (see Leifeld, 2013). As a result, the overall coalition structure remained relatively stable (Leifeld \& Haunss, 2012), and the policy outcome, i.e., limited mining limits rescission, ensured the continuation of the status quo within the subsystem.

\section{Acknowledgments}

The article reanalyzes the data from the MA thesis written by the first author (Černý, 2019). The authors would like to thank the Academic Editor, Philip Leifeld, and the two anonymous reviewers for their valuable comments, which helped substantially to improve the article, as well as Colin Kimbrell, who provided language editing services. The authors also thank Marína Urbániková and Lukáš Lehotský for useful suggestions. The article was written as part of the project 'Perspectives of European Integration in a Changing International Environment II' (MUNI/A/1044/2019).

\section{Conflict of Interests}

The authors declare no conflict of interest.

\section{Supplementary Material}

Supplementary material for this article is available online in the format provided by the authors (unedited).

\section{References}

Anopress. (n.d.). Czech media databse. Anopress. Retrieved from https://monitoring.anopress.cz/ anopress

Baumgartner, F. R., \& Jones, B. D. (1993). Agendas and instability in American politics. Chicago, IL: University of Chicago Press.

Broadbent, J., Sonnett, J., Botetzagias, I., Carson, M., Carvalho, A., Chien, Y.-J., . . . Zhengyi, S. (2016). Conflicting climate change frames in a global field of media discourse. Socius: Sociological Research for a Dynamic World, 2, 1-17. https://doi.org/10.1177/ 2378023116670660

Butts, C. T. (2008). Social network analysis with sna. Journal of Statistical Software, 24(6), 1-51. https://doi. org/10.18637/jss.v024.i06 
Černoch, F., Lehotský, L., Ocelík, P., Osička, J., \& Vencourová, Ž. (2019). Anti-fossil frames: Examining narratives of the opposition to brown coal mining in the Czech Republic. Energy Research \& Social Science, 54, 140-149. https://doi.org/10.1016/J.ERSS. 2019.04.011

Černý, O. (2019). Limity české energetické tranzice v politické perspektivě: prípad těžby uhlí [A political prespective on shortcomings of the Czech energy transition: A case of coal mining] (Masters dissertation). Masaryk University, Brno, Czech Republic.

Dalton, R. J., Recchia, S., \& Rohrschneider, R. (2003). Environmental movement and the modes of political action. Comparative Political Studies, 36(7), 743-771. https://doi.org/10.1177/0010414003255108

European Commission. (2017, February 1). Europe's energy transition is well underway. European Commission. Retrieved from https://ec.europa.eu/energy/ en/news/europes-energy-transition-well-underway

Fischer, M., \& Leifeld, P. (2015). Policy forums: Why do they exist and what are they used for? Policy Sciences, 48(3), 363-382. https://doi.org/10.1007/ s11077-015-9224-y

Geels, F. W. (2002). Technological transitions as evolutionary reconfiguration processes: A multi-level perspective and a case-study. Research Policy, 31(8/9), 1257-1274. https://doi.org/10.1016/S00487333(02)00062-8

Geels, F. W. (2014). Regime resistance against lowcarbon transitions: Introducing politics and power into the multi-level perspective. Theory, Culture \& Society, 31(5), 21-40. https://doi.org/10.1177/ 0263276414531627

Hahsler, M. M. (2019). Frequent item set mining. Wires Data Mining and Knowledge Discovery, 2(6), 437-456. https://doi.org/10.1002/widm.1074

Hajer, M. A. (1993). Discourse coalitions and the institutionalization of practice. In F. Fischer \& J. Forester (Eds.), The argumentative turn in policy analysis and planning (1st ed., pp. 43-67). Durham, NC: Duke University Press.

Hajer, M. A. (1995). The politics of environmental discourse: Ecological modernization and the policy process. Oxford: Oxford University Press.

Henry, A. D., Lubell, M. N., \& McCoy, M. (2011). Belief systems and social capital as drivers of policy network structure: The case of California regional planning. Journal of Public Administration Research and Theory, 21(3), 419-444. https://doi.org/10.1093/jopart/ muq042

Ingold, K., Fischer, M., \& Cairney, P. (2017). Drivers for policy agreement in nascent subsystems: An application of the advocacy coalition framework to fracking policy in Switzerland and the UK. Policy Studies Journal, 45(3), 442-463. https://doi.org/10.1111/psj. 12173

International Energy Agency. (2018). CO2 emissions from fuel combustion 2018: Overview. Paris: Inter- national Energy Agency. Retrieved from https:// webstore.iea.org/co2-emissions-from-fuelcombustion-2018-overview

Johnstone, P., Stirling, A., \& Sovacool, B. (2017). Policy mixes for incumbency: Exploring the destructive recreation of renewable energy, shale gas 'fracking,' and nuclear power in the United Kingdom. Energy Research \& Social Science, 33, 147-162. https://doi. org/10.1016/J.ERSS.2017.09.005

Koopmans, R. (2002). Codebook for the analysis of political mobilisation and communication in European public spheres (D 2.1). Berlin: EUROPUB.COM.

Kukkonen, A., Ylä-Anttila, T., \& Broadbent, J. (2017). Advocacy coalitions, beliefs and climate change policy in the United States. Public Administration, 95(3), 713-729. https://doi.org/10.1111/padm.12321

Lehotský, L., Černoch, F., Osička, J., \& Ocelík, P. (2019). When climate change is missing: Media discourse on coal mining in the Czech Republic. Energy Policy, 129, 774-786. https://doi.org/10.1016/j.enpol.2019. 02.065

Leifeld, P. (2013). Reconceptualizing major policy change in the advocacy coalition framework: A discourse network analysis of German pension politics. Policy Studies Journal, 41(1), 169-198. https://doi.org/10.1111/ psj.12007

Leifeld, P. (2016). Policy debates as dynamic networks: German pension politics and privatization discourse. Chicago, IL: University of Chicago Press.

Leifeld, P. (2017). Discourse network analysis: Policy debates as dynamic networks. In J. N. Victor, A. H. Montgomery, \& M. N. Lubell (Eds.), The Oxford handbook of political networks (pp. 301-325). Oxford: Oxford University Press.

Leifeld, P. (2019). Discourse Network Analyzer (2.0 beta 24). Retrieved from http://github.com/leifeld/dna

Leifeld, P., Gruber, J., \& Bossner, F. R. (2019). Discourse network analyzer manual. Retrieved from https:// usermanual.wiki/Pdf/dnamanual.1699447373/view

Leifeld, P., Gruber, J., \& Henrichsen, T. (2019). rDNA: A package to control discourse network analyzer from R. (2.1.16.). Github. Retrieved from https://github. com/leifeld/dna/tree/master/rdna

Leifeld, P., \& Haunss, S. (2012). Political discourse networks and the conflict over software patents in Europe. European Journal of Political Research, 51(3), 382-409. https://doi.org/10.1111/j.14756765.2011.02003.x

Markard, J., Suter, M., \& Ingold, K. (2016). Sociotechnical transitions and policy change: Advocacy coalitions in Swiss energy policy. Environmental Innovation and Societal Transitions, 18, 215-237. https:// doi.org/10.1016/J.EIST.2015.05.003

McCombs, M. E., \& Shaw, D. L. (1972). The agendasetting function of mass media. Public Opinion Quarterly, 36(2), 176-187.

Ministry of Industry and Trade. (2015). State Energy Policy of the Czech Republic (Act No. 406/2000 Coll.). 
Prague: Ministry of Industry and Trade.

Ocelík, P., Svobodová, K., Hendrychová, M., Lehotský, L., Everingham, J.-A., Ali, S., Badera, J., \& Lechner, A. (2019). A contested transition toward a coal-free future: Advocacy coalitions and coal policy in the Czech Republic. Energy Research \& Social Science, 58, 1-13. https://doi.org/10.1016/J.ERSS.2019.101283

Osička, J., \& Černoch, F. (2017). Anatomy of a black sheep: The roots of the Czech Republic's pro-nuclear energy policy. Energy Research \& Social Science, 27, 9-13. https://doi.org/10.1016/J.ERSS.2017.02.006

Osička, J., Kemmerzell, J., Zoll, M., Lehotský, L., Černoch, F., \& Knodt, M. (2020). What's next for the European coal heartland? Exploring the future of coal as presented in German, Polish and Czech press. Energy Research \& Social Science, 61. https://doi.org/10.1016/ J.ERSS.2019.101316

Petrova, T., \& Tarrow, S. (2007). Transactional and participatory activism in the emerging European polity. Comparative Political Studies, 40(1), 74-94. https:// doi.org/10.1177/0010414006291189

R Core Team. (2014). R: A language and environment for statistical computing. Retrieved from http://www. r-project.org

Sabatier, P. A. (1988). An advocacy coalition framework of policy change and the role of policy-oriented learning therein. Policy Sciences, 21(2/3), 129-168.

Saunders, C. (2009). It's not just structural: Social movements are not homogenous responses to structural features, but networks shaped by organisational strategies and status. Sociological Research Online, 14(1), 26-41. https://doi.org/10.5153/sro.1856

Schmidt, V. A. (2008). Discursive institutionalism: The explanatory power of ideas and discourse. Annual Review of Political Science, 11(1), 303-326. https://doi. org/10.1146/annurev.polisci.11.060606.135342

Shanahan, E. A., Jones, M. D., \& McBeth, M. K. (2011).
Policy narratives and policy processes. Policy Studies Journal, 39(3), 535-561. https://doi.org/10.1111/ j.1541-0072.2011.00420.x

Smink, M. (2015). Incumbents and institutions in sustainability transitions (Doctoral dissertation). University of Utrecht, Utrecht, The Netherlands.

Snow, D. A., \& Benford, R. D. (1988). Ideology, frame resonance, and participant mobilization. In B. Klandermans, H. Kriesi, \& S. G. Tarrow (Eds.), From structure to action: Social movement participation across cultures (pp. 197-217). Stamford, CT: JAI Press.

Stoddart, M. C. J., \& Tindall, D. B. (2015). Canadian news media and the cultural dynamics of multilevel climate governance. Environmental Politics, 24(3), 401-422. https://doi.org/10.1080/09644016.2015.1008249

Vlček, T., Černoch, F., Zapletalová, V., Trmalová, E., Červinková, J., Brhlíková, P., . . \& Bendlová, P. (2019). The energy sector and energy policy of the Czech Republic (2nd ed.). Brno: Masaryk University Press.

Volek, J., \& Urbániková, M. (2017). Čeští novináři v komparativní perspektivě [Czech journalists in comparative perspective]. Lublanska: Academia.

Weible, C. M. (2008). Expert-Based Information and Policy Subsystems: A review and synthesis. Policy Studies Journal, 36(4), 615-635. https://doi.org/10.1111/ j.1541-0072.2008.00287.x

Weible, C. M., Pattison, A., \& Sabatier, P. A. (2010). Harnessing expert-based information for learning and the sustainable management of complex socioecological systems. Environmental Science and Policy, 13(6), 522-534. https://doi.org/10.1016/j.envsci. 2010.05.005

White, H. C., Boorman, S. A., \& Breiger, R. L. (1976). Social structure from multiple networks: I blockmodels of roles and positions. American Journal of Sociology, 81(4), 730-780.

\section{About the Authors}
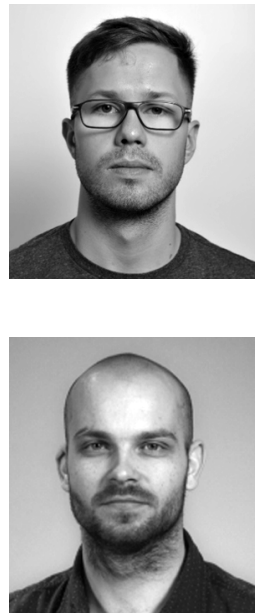

Ondřej Černý holds a BA degree in Power Electrical and Electronic Engineering from the Brno University of Technology, and a MA degree in Energy Security Studies from the Department of International Relations and European Studies, Masaryk University. He works as a Consultant and Researcher for policy consultancy company Trinomics with a focus on European energy policy and energy networks.

Petr Ocelík is Assistant Professor at the Department of International Relations and European Studies, Masaryk University, and a Researcher at the International Institute of Political Science, Masaryk University. He was a Guest Researcher at the Sustainable Minerals Institute, University of Queensland. Petr is also Vice-Chair of the Standing Group on Political Networks at the European Consortium for Political Research. His research focuses on analysis of policy processes in energy and climate subsystems. 